$\$$

\title{
Effects of gallium, indium, and arsenic dose biomarkers and malondialdehyde on zinc protoporphyrin and DNA fragments in optoelectronic workers
}

\author{
Yeh-Hsiung Liao \\ Department of Health Sciences, School of Public Health, Kaohsiung Medical University, Taiwan \\ E-mail: bany0309@yahoo.com.tw
}

\begin{abstract}
Purpose: To investigate whether occupational exposure to gallium, indium, and arsenic may disrupt normal heme production and damage DNA by initiating the release of lipid peroxidation.

Methods: 101exposed optoelectronic workers and 65 referents were tested for their whole blood and urine levels of gallium, indium, and arsenic. Plasma malondialdehyde (MDA), blood zinc protophorphyrin (ZPP), and serum DNA fragments were used as indicators of toxic hazards.

Results: The MDA, ZPP, and DNA fragment mean levels in the exposed workers were significantly higher than those in the referents. The levels of urine gallium in the exposed workers were significantly correlated with the levels of whole blood ZPP and serum DNA fragments respectively. MDA (the production of lipid peroxidation) may be one of the mechanisms for gallium-related DNA damage in multiple regression models. In addition, gallium was found to have a synergistic effect with arsenic on MDA level that may induce indium to damage DNA in blood cells.

Conclusion: ZPP and DNA fragments can be elevated by gallium exposure, and the MDA increase due to combined exposure to gallium and arsenic may play a role in indium-induced DNA damage.
\end{abstract}

Keywords: Optoelectronic; ZPP; DNA Fragments.

\section{Introduction}

Optoelectronic manufacturing is a metallic-intensive modern industry. The optoelectronic industry has been a rapidly expanding industrial sector in many countries. Toxic metals of the periodic table group III A and VA are widely used in the semiconductor and optoelectronic industries (Robinson 1983, Edelman 1990, Fowler et al. 1993). Occupational exposure to gallium (Ga), indium (In), and arsenic (As) habe been described as significantly higher in these exposed groups than in the referents (Liao et al 2004). These metals or metalloids are known to alter several cellular functions, initiate apoptosis, and cause carcinogenic effects in mammals (Fowler et al. 1993. Woods et al. 1979, Aoki et al. 1990, Chang et al. 2003, Zhou et al. 2005). Liao et al found correlations between the levels of urine $\mathrm{Ga}$ and as, and the plasma levels of MDA in optoelectronic workers (Liao et al. 2006).

ZPP, which indicates a disruption of normal heme production, is widely accepted as a general mechanism for $\mathrm{Pb}$ poising, iron deficiency, chronic inflammatory disorder, and porphyrias (Chisolm et al. 1975, Rosel et al. 1990, Hastka et al. 1993, HarthoornLasthuizen \& Sant 2000). Rossi et al showed that human lymphocyte ferrochelatase was inhibited by in vitro $\mathrm{Cu}$ and $\mathrm{Hg}$ (Rossi et al. 1990). In addition, Labbe noted that a variety of metals (Pb, $\mathrm{Cd}$, and $\mathrm{Hg}$ ) that react with sulfhydryl $(-\mathrm{SH})$ groups are capable of inhibiting purified ferrochelatase (Labbe et al. 1987). DNA fragments indicate damage to DNA before cell death, which also acts as an initial hallmark of apoptosis (Distelharst 1988, Konishi et al.
2003). This oxidative damage may play an important role in many pathological conditions like cancer, autoimmunity conditions, and Alzheimer's disease (Oehm et al. 1992, Carson \& Ribeiro 1993, Hegde et al. 2004).

Optoelectronic manufacturing is a modern metallic-intensive industry. In the field of occupational and environmental health, the effects of $\mathrm{Ga}$, in, and as on human erythropoiesis and DNA synthesis have not been fully investigated. ZPP is a specific element to evaluate if employees are at increased risk for material impairment to their heme synthesis (Distelharst 1988). DNA fragmentation is a sensitive and specific aspect to evaluate whether employees are at risk of oligonucleosome impairment to the appropriate regulation of cell functions (Bonfoco et al. 1995, Uwai et al. 2000, Mishima et al. 2002). In this study, the blood MDA, ZPP and DNA fragment levels of optoelectronic workers were determined in an attempt to be established whether occupational exposure to $\mathrm{Ga}$, in and as may disrupt a normal heme production and DNA synthesis by initiating the release of lipid peroxidation.

\section{Methods}

\subsection{Subjects}

The study population included 103 optoelectronic workers and a reference group of 67 controls from industrial located in the north of Taiwan. There were no workers with iron-deficiency anemia, or with anemia of chronic disorder. Four workers were excluded 
because of having past history of thyroid, and tumor disease. Therefore, the final study population consisted of 101 optoelectronic workers (15 fabrication equipment preventative workers, 51 dopants and thin film workers, and 36 fabrication supervisors and engineers). The general characteristics of the exposed workers and referents are shown in Table1. The study was approved by the Institutional Review Board in Kaohsiung Medical University. All participants were informed and signed consent forms.

\subsection{Collection and analysis of biomonitoring specimens}

Personal first spot of urine specimen in the morning and blood sample from the antecubital vein were obtained from the study subjects during their health check- ups. Subjects were instructed to eat nothing for at least 8 hours prior to blood and urine sampling. Blood and urine specimens were kept at $-20 \mathrm{oC}$ prior to analysis (Pan 1993). The levels of heavy metals were determined by inductively coupled plasma-mass spectrometry after microwave dissolution. The methods for metals and MDA analysis have been previously presented (Liao ET al.2004, Liao et al. 2006). The detection limits (3SD of 10 unexposed urban residents) of blood $\mathrm{Ga}$, in, and as were $0.016 \mu \mathrm{g} / \mathrm{L}, 0.081 \mu \mathrm{g} / \mathrm{L}$, and $0.970 \mu \mathrm{g} / \mathrm{L}$. The detection limits of urine $\mathrm{Ga}$, in, and as were $0.101 \mu \mathrm{g} / \mathrm{L}, 0.005 \mu \mathrm{g} / \mathrm{L}$, and $9.980 \mu \mathrm{g} / \mathrm{L}$. The measurements below a concentration of detection limits were set at half of the detection. MDA was determined by high-performance liquid chromatography. The coefficient of variation for the interassay of precision was $3.83 \%$ the coefficient of variation for the intraassay of precision was $5.08 \%$.

\subsection{Determination of whole blood ZPP and serum DNA fragments}

Blood (whole blood in EDTA) was collected, and $1 \mathrm{ml}$ whole blood was transported. Care was taken not to exposure to light contamination. The blood was stored at $2-80 \mathrm{C}$

For no longer than five wk prior to analysis. ZPP levels in blood were measured with a hematofluorometer (Aviv Lakewood, New Jersey, USA). There were no hemolyzed, or clotted samples. Serum was taken from the supermatants of centrifuged blood. The serum was stored at 2-8 oC for no longer than five wk prior to analysis. Histone- associated-DNA-Fragments level $(\mathrm{mU}=\mathrm{ab}-$ sorbance [10-3] was measured using cell death detection ELISA kit (Roche, Cat. No. 11774425001, Germany). The $20 \mu 1$ of serum was transferred to a 96-well micro-titer plate. After adding $80 \mu$ l of immune reagent to each well, samples were incubated on a MP shaker for two hours at $15-25 \mathrm{oC}$. Wells were washed, and each well pipette with $100 \mu \mathrm{l}$ of ABT substrate solution. Absorbance was measured at $450 \mathrm{~nm}$ (reference wavelength: 690nm)(Hingst \& Blottner 1995).

\subsection{Statistics}

All results were presented as the value of means, or median. When two groups were compared. The Student's test or Chi-square test were employed. The limit of significance was set at $p<0.05$. The correlation in the various groups was studied by Pearson's regression after the data had been normalized. The data were also subjected to multiple linear regression models using the SPSS program (SPSS Inc, Chicago, IL) for Windows.

\section{Results}

Tablel shows the demographic data by exposure situation. There was a higher proportion of males, smoking habit, and consuming vitamin complex tablets regularly in the exposed group than in referents.
Table 1: Subjects Characteristics of Exposed Workers $(\mathrm{N}=101)$ and Referents $(\mathrm{N}=65)$.

\begin{tabular}{lll}
\hline Items & Exposure group & Referents \\
\hline Median & & \\
Duration of employment (months) & 22.80 & 24.00 \\
Age $(\mathrm{yrs})$ & 28.20 & 29.07 \\
Body mass index $\left(\mathrm{kg} / \mathrm{m}^{2}\right)$ & 22.32 & 23.00 \\
Sex* & & \\
male & 62 & 22 \\
female & 39 & 43 \\
Education level & & \\
$<$ college & 80 & 51 \\
ミcollege & 21 & 14 \\
Smoking status* & & \\
no & 81 & 61 \\
yes & 20 & 4 \\
Alcohol consumption & & 59 \\
no & 88 & 6 \\
yes & 13 & 58 \\
Vitamin complex intake* & & 7 \\
no & 75 & \\
yes & 26 & \\
\hline
\end{tabular}

$* \mathrm{X}^{2}$ test: exposure group versus referents, $\mathrm{df}=1, \mathrm{p}<0.05$.

\subsection{Exposure and health outcome measures}

The levels of metals, MDA, ZPP, and DNA fragments in subjects are shown in table 2 . The mean blood in $(0.22 \pm 0.17 \mathrm{ppb})$, urine $\mathrm{Ga}(0.24 \pm 0.22 \mathrm{ppb})$, and as $(32.69 \pm 27.06 \mathrm{ppb})$, plasma MDA $(0.98 \pm 0.44 \mu \mathrm{mol} / \mathrm{L})$, blood ZPP $(36.46 \pm 5.81 \mu \mathrm{mol} / \mathrm{mol}$ heme $)$, and serum DNA fragments levels $(240.37 \pm 41.78 \mathrm{mU})$ were significantly higher in the occupationally exposed workers than in the referents.

Table 2: Metal Levels (Ppb), MDA (Mmol/L), ZPP (Mmol /Mol Heme) and DNA Fragmentation $(\mathrm{Mu})$ in Blood and Urine among the Exposed Workers $(\mathrm{N}=101)$ and Referents $(\mathrm{N}=65)$.

\begin{tabular}{|c|c|c|c|}
\hline Body fluid & $\begin{array}{l}\text { Parameter exam- } \\
\text { ined }\end{array}$ & $\begin{array}{l}\text { Exposure } \\
\text { group }\end{array}$ & Referents \\
\hline \multirow[t]{4}{*}{$\begin{array}{l}\text { Blood } \\
\text { (median) }\end{array}$} & $\mathrm{Ga}$ & $\begin{array}{l}0.51 \pm 0.34 \\
(0.47)\end{array}$ & $\begin{array}{l}0.48 \pm 0.23 \\
(0.46)\end{array}$ \\
\hline & In* & $\begin{array}{l}0.22 \pm 0.17 \\
(0.17)\end{array}$ & $\begin{array}{l}0.14 \pm 0.12 \\
(0.11)\end{array}$ \\
\hline & As & $\begin{array}{l}8.70 \pm 6.36 \\
(7.25)\end{array}$ & $\begin{array}{l}7.89 \pm 6.60 \\
(6.78)\end{array}$ \\
\hline & $\mathrm{Pb}$ & $\begin{array}{l}34.49 \pm \\
11.29 \\
(34.78)\end{array}$ & $\begin{array}{l}32.05 \pm \\
12.55 \\
(31.49)\end{array}$ \\
\hline \multirow[t]{4}{*}{ Urine } & $\mathrm{Ga}^{*}$ & $\begin{array}{l}0.24 \pm 0.22 \\
(0.19)\end{array}$ & $\begin{array}{l}0.15 \pm 0.09 \\
(0.15)\end{array}$ \\
\hline & In & $\begin{array}{l}0.03 \pm 0.04 \\
(0.01)\end{array}$ & $\begin{array}{l}0.02 \pm 0.03 \\
(0.01)\end{array}$ \\
\hline & $\mathrm{As}^{*}$ & $\begin{array}{l}32.69 \pm \\
27.06 \\
(25.49)\end{array}$ & $\begin{array}{l}24.65 \pm \\
22.68 \\
(22.66)\end{array}$ \\
\hline & $\mathrm{Pb}$ & $\begin{array}{l}29.72 \pm \\
16.54 \\
(25.90)\end{array}$ & $\begin{array}{l}26.64 \pm \\
19.57 \\
(22.50)\end{array}$ \\
\hline Plasma & MDA* & $\begin{array}{l}0.98 \pm 0.44 \\
(0.96)\end{array}$ & $\begin{array}{l}0.67 \pm 0.33 \\
(0.67)\end{array}$ \\
\hline Blood & ZPP* & $\begin{array}{l}36.46 \pm 5.81 \\
(35.58)\end{array}$ & $\begin{array}{l}29.32 \pm 4.62 \\
(28.75)\end{array}$ \\
\hline $\begin{array}{l}\text { Serum histone- } \\
\text { associated } \\
\text {-DNA-fragments* }\end{array}$ & & $\begin{array}{l}240.37 \pm \\
41.78 \\
(239.09)\end{array}$ & $\begin{array}{l}209.72 \pm \\
46.11 \\
(210.72)\end{array}$ \\
\hline
\end{tabular}

*: Student's t test, significant difference, $\mathrm{p}<0.05$ (exposed workers vs. referents, $\mathrm{df}=1$, all data had been normalized).

\subsection{Associations between metals and health outcome measures}

Among the 101 optoelectronic workers, urine Ga levels were positively and significantly correlated $(p<0.05)$ with plasma MDA, blood ZPP, and serum DNA fragment levels respectively $(\mathrm{r}=0.35$, 0.47 , and 0.39). Blood In levels were correlated $(\mathrm{r}=0.26, \mathrm{p}<$ $0.05)$ with serum DNA fragments. Urine As levels was correlated $(\mathrm{r}=0.22, \mathrm{p}<0.05)$ with plasma MDA levels. As indicators of 
health outcomes in exposed workers, plasma MDA levels were positively and significantly correlated $(r=0.43, p<0.05)$ with serum DNA fragments, but were not significantly correlated with blood ZPP levels in the exposed group. There were no any significant correlations between metals in blood or in urine and plasma MDA, blood ZPP, and serum DNA fragments in the referents (Table3).

Table 3: Pearson's Correlation Coefficient between Metal Levels in Blood, Urine, Plasma, MDA, Blood ZPP, and Serum DNA Fragments (DNAF) Levels.

\begin{tabular}{llll}
\hline Parameter & Exposure group & Referents & Total \\
\hline Blood & & & \\
In vs MDA & 0.09 & 0.07 & 0.15 \\
In vs ZPP & 0.19 & 0.09 & 0.18 \\
In vs DNAF & $0.26^{*}$ & -0.04 & $0.22^{*}$ \\
Urine & & & \\
Ga vs MDA & $0.35^{*}$ & $0.30^{*}$ & $0.37^{*}$ \\
Ga vs ZPP & $0.47^{*}$ & -0.02 & $0.32^{*}$ \\
Ga vs DNAF & $0.39^{*}$ & 0.26 & $0.39^{*}$ \\
As vs MDA & $0.22^{*}$ & -0.09 & 0.17 \\
As vs ZPP & 0.14 & 0.06 & 0.13 \\
As vs DNAF & 0.09 & -0.04 & 0.09 \\
Blood & & & \\
MDA vs ZPP & 0.14 & 0.14 & 0.16 \\
MDA vs DNAF & $0.43^{*}$ & 0.05 & $0.30^{*}$ \\
\hline
\end{tabular}

*: significant difference, $\mathrm{p}<0.05$, (all data had been normalized).

\subsection{Effects of MDA adjustments on Ga level associa- tions with ZPP and DNA fragments measure models}

Associations between the urine Ga and the health outcomes, after adjustment for MDA were modeled in the exposed workers because the association of Ga biomarker with MDA and the associations between higher Ga dose and ZPP levels and DNA fragments were also found in the exposed group. As shown in table 4, association between the Ga measures and DNA fragments remained significant after adjustment for MDA. The regression coefficient ( $\beta$ ) of urine, Ga was $0.328(\mathrm{p}<0.05)$. Other risk factors such as MDA $(\beta=0.314, p<0.05)$, cigarette smoking $(\beta=0.301, p<$ $0.05)$, and alcohol consumption $(\beta=-0.221, p<0.05)$ also significantly affected the serum DNA fragmentation. Association between the Ga measures and ZPP levels remained constant after adjustment for MDA also. Other risk factors such as blood $\mathrm{Pb}$ levels, age, duration of employment, body mass index, sex, education levels, cigarette smoking, and alcohol consumption, when analyzed all the regression coefficients $(\beta)$ did not significantly affect the blood ZPP levels.

Table 4: Linear Regression Models to Evaluate Association of Urine Ga and Plasma MDA Dose with Blood ZPP and Serum DNA Fragments Levels in 101 Optoelectronic Workers.

\begin{tabular}{|c|c|c|c|}
\hline Model & Model1 (Ga) & $\begin{array}{l}\text { Model2 } \\
\text { (MDA ) }\end{array}$ & $\begin{array}{l}\text { Model } 3 \text { ( com- } \\
\text { bine ) }\end{array}$ \\
\hline Variables & $\beta p$ value & $\beta$ p value & $\beta \mathrm{p}$ value \\
\hline $\begin{array}{l}\text { DNA fragments } \\
\text { models }\end{array}$ & $\begin{array}{l}\left(\mathrm{R}^{2}=0.20, \mathrm{p}\right. \\
<0.05)\end{array}$ & $\begin{array}{l}\left(\mathrm{R}^{2}=0.13, \mathrm{p}<\right. \\
0.05)\end{array}$ & $\begin{array}{l}\left(\mathrm{R}^{2}=0.28, \mathrm{p}<\right. \\
0.05)\end{array}$ \\
\hline Urine $\mathrm{Ga}$ & $0.447 \mathrm{p}<0.05$ & & $0.328 p<0.05$ \\
\hline $\begin{array}{l}\text { MDA } \\
\text { Smoking status }\end{array}$ & & $0.346 \mathrm{p}<0.05$ & $0.314 \mathrm{p}<0.05$ \\
\hline no vs yes & $0.260 p<0.05$ & & $0.301 \mathrm{p}<0.05$ \\
\hline $\begin{array}{l}\text { Alcohol consump- } \\
\text { tion } \\
\text { no vs yes }\end{array}$ & & $\begin{array}{l}-0.242 p< \\
0.05\end{array}$ & $-0.221 \mathrm{p}<0.05$ \\
\hline ZPP models & $\begin{array}{l}\left(\mathrm{R}^{2}=0.22, \mathrm{p}\right. \\
<0.05)\end{array}$ & $\begin{array}{l}\left(\mathrm{R}^{2}=0.07, \mathrm{p}>\right. \\
0.05)\end{array}$ & $\begin{array}{l}\left(\mathrm{R}^{2}=0.21, \mathrm{p}<\right. \\
0.05)\end{array}$ \\
\hline $\begin{array}{l}\text { Urine Ga } \\
\mathrm{MDA} \\
\mathrm{Pb}\end{array}$ & $0.472 p<0.05$ & & $0.464 p<0.05$ \\
\hline
\end{tabular}

\subsection{Associatios of blood in levels with DNA fragmenta- tion by MDA levels above and below the median respec- tively}

Different associations of blood in levels with DNA fragments were evident when workers with plasma MDA levels above and less than or equal $0.96 \mu \mathrm{mol} / \mathrm{L}$ were compared (Table 5). The regression coefficients $(\beta)$ of blood in, duration of employment, cigarette smoking, and alcohol consumption was $0.284,0.318$, and -0.287 respectively (all $p<0.05$ ) in serum DNA fragments for workers with plasma MDA levels above $0.96 \mu \mathrm{mol} / \mathrm{L}$. The association of blood in levels with DNA fragments was more pronounced at MDA levels above $0.96 \mu \mathrm{mol} / \mathrm{L}$

Table 5: Linear Regression Models of DNA Fragments on Blood in Levels By MDA Level above and Below $0.96 \mathrm{Mmol} / \mathrm{L}$ (Median) in 101 Optoelectronic Workers.

\begin{tabular}{lll}
\hline Variables & $\begin{array}{l}\text { MDA }>\text { median } \\
\beta \mathrm{p} \text { value }\end{array}$ & $\begin{array}{l}\text { MDA }>\text { median } \\
\beta \mathrm{p} \text { value }\end{array}$ \\
\hline & $\left(\mathrm{R}^{2}=0.25, \mathrm{p}<0.05\right)$ & $\left(\mathrm{R}^{2}=0.16, \mathrm{p}>0.05\right)$ \\
$\begin{array}{l}\text { Number } \\
\text { Blood In }\end{array}$ & 50 & 51 \\
$\begin{array}{l}\text { Duration of employment } \\
\text { Smoking status } \\
\text { no vs yes }\end{array}$ & $0.284 \mathrm{p}<0.05$ & $0.268 \mathrm{p}>0.05$ \\
$\begin{array}{l}\text { Alcohol consumption } \\
\text { no vs yes }\end{array}$ & $0.318 \mathrm{p}<0.05$ & \\
\hline $\mathrm{P}$ value $<0.05$, significant difference. All models were also adjusted for
\end{tabular}
age, sex, BMI. Educational level and consuming vitamin complex tablets.

\subsection{Synergistic effect of exposure to Ga and As on MDA measures}

Table 6 summarized the characteristics of study subjects stratified by median levels of urine $\mathrm{Ga}(0.19 \mathrm{ppb})$ and as $(25.49 \mathrm{ppb})$ in a different exposure group. The median plasma MDA level was significantly higher in the $\mathrm{H}-\mathrm{Ha}$ and $\mathrm{H}-\mathrm{As}$ group than in the L-Ga and $\mathrm{H}-\mathrm{As}$ group, as well as in the L-Ga and L-As group respectively. The median BMI was significantly higher in the $\mathrm{H}-\mathrm{Ga}$ and $\mathrm{L}$-As group than in the L-Ga and $\mathrm{H}$-As group, as well as in the L$\mathrm{Ga}$ and L-As group respectively. All other characteristics such as duration of employment, alcohol consumption, cigarette smoking, sex, age, and education level were not statistically significant between these four exposure groups respectively. Thus, there is a synergistic effect of Ga and as exposure on MDA level.

Table 6: Characteristics of Study Sybjects $(\mathrm{N}=101)$ Stratified by Median Levels of Urine $\mathrm{Ga}(0.19 \mathrm{Ppb})$ and as $(25.49 \mathrm{ppb})$ in the Optoelectronic Industry.

\begin{tabular}{lllll}
\hline Exposure & $\begin{array}{l}\text { H-Ga \& H- } \\
\text { As }\end{array}$ & $\begin{array}{l}\text { H-Ga \& L- } \\
\text { As }\end{array}$ & $\begin{array}{l}\text { L-Ga \& H- } \\
\text { As }\end{array}$ & $\begin{array}{l}\text { L-Ga \& L- } \\
\text { As }\end{array}$ \\
\hline Number & 30 & 22 & 22 & 27 \\
MDA* $^{*}$ & 1.18 & 1.03 & $0.90^{\mathrm{a}}$ & $0.80^{\mathrm{a}}$ \\
BMI $^{*}$ & 23.2 & 24.7 & $21.7^{\mathrm{b}}$ & $21.7^{\mathrm{b}}$ \\
\hline
\end{tabular}

H: median level, L: < median level. * kruska-Wallis $\mathrm{H}$ test, $\mathrm{p}<0.05$ (all categories of exposed groups, $\mathrm{df}=3),{ }^{\mathrm{a}}$ Mann-Whitney test, $\mathrm{p}<0.05(\mathrm{H}-$ Ga \& H-As vs L-Ga \& H-As, and L-Ga \& L-As respectively, $\mathrm{df}=1)$. Mann-Whitney test, $\mathrm{p}<0.05$ (H-Ga \& L-As vs L-Ga \& H-As, and L-Ga \& L-As respectively, $\mathrm{df}=1$ )

\section{Discussion}

This study showed an elevated blood In, urine Ga, urine. As, plasma MDA, blood ZPP, and serum DNA fragment levels in workers exposed to Ga, In, and As when compared with the referents. Association between increased MDA and higher Ga and as measures were found. In addition, serum DNA fragments were significantly correlated with urine $\mathrm{Ga}$ and blood. In levels. Blood ZPP levels were correlated with urine Ga levels only. These results suggest that heavy exposure to Ga may possibly disrupt a function of heme synthesis and a structure of DNA in human blood cells Urine Ga affecting DNA fragments was observed in participants in the exposed workers after adjustment for duration of employment, 
alcohol consumption, smoking status, sex, age, education level, BMI, and consuming vitamin complex tablets. The association was diminished after adjustment for plasma MDA, although urine Ga remained significantly associated with DNA fragments in the 101 workers. The data indicated an effect of Ga on DNA fragmentation beyond that due to Ga exposure alone, and because MDA was associated with adverse DNA fragmentation and reduced the significance of the Ga biomarker association with DNA fragments in the exposed workers. Therefore, MDA may be one but not the only one mechanism by which Ga is cytopathogenetic to DNA fragmentation. MDA was not associated with adverse heme synthesis, and did not result in reducing the significance of $\mathrm{Ga}$ biomarker association with ZPP in the exposed workers. These results imply that the mechanism of Ga-induced dose-dependent ZPP and DNA fragments are different.

$\mathrm{Ga}$ resembles iron with respect to transferring-gallium (Tf-Ga) complexes result in iron deprivation that inhibits cellular proliferation and hemoglobin production (Chitambar \& Zorica 1987, Willianm et al. 1996). The antiproliferative activity of Tf-Ga appears to be the result of a blockade of ribonucleotide reductase. This occurs both directly, by interfering with iron incorporation into the iron-containing M2 subunit of the enzyme (Chitambar et al. 1991, Narasimhan et al. 1992), and indirectly, by depriving the cell of intracellular iron necessary for ribonucleotide reductase activity (Chitambar et al. 1988). The enhancement of lipid peroxidation may help metal cause promutagenic damage that includes DNA base modifications, inter- and intramolecular crosslinking of DNA and proteins, DNA strand breaks, rearrangements, and depurination (Kasparzake 1995). Recent studies have shown that cellular uptake of $\mathrm{Ga}$ leads to activation of caspases and induction of apoptosis (Chitambar 2004). The Tf-Ga can also inhibit the hemoglobin synthetic pathway by decreasing the iron incorporation into heme, which indirectly accumulates zinc protoporphyrin in blood cells (Chitambar \& Zorica 1987, Labbe et al. 1987).

Levels of MDA in the exposed workers were correlated significantly with the levels of urine Ga and as. However, urine Ga was the only significant risk factor, accounting for $33.9 \%$ of the affects on plasma MDA level. Table 5 shows that exposure to Ga had a synergistic effect with As on lipid peroxidation of blood in the exposed workers. The results imply that combined exposure to $\mathrm{Ga}$ and As shows a dose-response relationship in association with MDA levels, although as is not the major risk factor.

The correlation between blood In levels and serum DNA fragments levels was modified by MDA levels in the optoelectronic workers. This sign was most pronounced at plasma MDA levels > median $(0.96 \mu \mathrm{mol} / \mathrm{L})$. We showed that $\mathrm{Ga}$ and As induced lipid peroxidation activity in cell membrane, and thus hypothesize that MDA is a risk factor that induces indium penetration and damage to the inner nucleus by forming larger lipidic pores in the cell membrane.

In regression analysis, urine Ga level was the only factor affecting blood ZPP. Socioeconomic status and blood $\mathrm{Pb}$ did not affect blood ZPP levels significantly. Many studies have suggested that iron deficiency, chronic inflammatory, and $\mathrm{Pb}$ exposure could disrupt heme synthesis (Hastka et al. 1993, Alexander et al. 1998, Roh et al. 2000). The level of ZPP in erythrocytes may be 5- to 10fold greater than normal levels in anemia of iron-deficiency or chronic disorders. It may be 10 - to 250 - fold greater than normal levels of ZPP level in clinically manifest $\mathrm{Pb}$ poising and in protoporphyria (Dagg et al. 1966, Granick et al. 1972, Hastka et al. 1993). We found that none of the workers had iron-deficiency anemia, or anemia of chronic disorder. We also found that the mean level of ZPP in exposed workers was about 1.2- fold $(36.46 / 29.32=1.2)$ greater than the referents. We also found that the blood $\mathrm{Pb}$ mean levels in exposed workers (median $=34.78$ $\mathrm{ppb}$ ) were not significantly higher than blood $\mathrm{Pb}$ mean level in the referents (median $=31.49 \mathrm{ppb}$ ). According to these results, ZPP, as an index of disruption of heme synthesis may be ruled out by $\mathrm{Pb}$ exposure in this study.

The BMI did not affect the plasma MDA levels, although there were different BMI in exposed subgroups. Therefore, as a con- founding factor BMI could be ruled out in the study of synergistic effect of exposure to Ga and As analyses. The highly reactive chemicals such as hydrogen fluoride, and fluoride compounds might induce the lipid peroxidation, DNA damage and apoptosis in animal cells (Wang et al. 2004, He \& Chen 2006). These chemicals were most used in the etching operation room. In this study, theexposed workers who were employed in the operation of dopant and epitaxy. Theprocess usually use a lot of metals of a periodic table group IIIA and VA in the thin film room. They often submitted the processes of photolithography and etching to other contract companies. Therefore, the possible effects of the strong acid and solvent on lipid peroxidation, ZPP, and DNA fragmentation will be estimated in the future.

\section{Conclusion}

According to these findings, occupational exposure to Ga could increase the blood ZPP and DNA fragment's levels in optoelectronic industry workers. MDA may be one, but not the only, mechanism for Ga- related DNA damage. Together with exposure to As, Ga has a synergistic effect on MDA formation, which may change the cell membrane permeability and then induce indium to damage DNA in the cellular nucleus.

\section{Acknowledgments}

This study was financially supported by the Shin Horng Machinery Individual Company Taichung, Taiwan.

\section{References}

[1] Alexander BH, Checkoway H, Costa-Mallen P, Faustman EM, Woods JS, Kelsey KT, Netten C, \& Costa LG (1998). Interaction of blood Pb and [delta] - aminolevulinic acid dehydratase genotype on markers of heme synthesis and sperm production in $\mathrm{Pb}$ smelter workers. Environmental Health Perspective 106, 213 - 216.

[2] Aoki Y, Lipsky MM, \& Fowler BA (1990). Alternation of protein synthesis in primary culture of rat kidney epithelial cells by exposure to Ga, in, and as (1990). Toxicology \& Apl Pharm 106, $462-468$.

[3] Bonfoco E, Krainc D, Ankarcrona M, Nicotera P, \& Lipton SA (1995). Apoptosis and necrosis: two distinct events induced, respectively, by mild and intense insults with $\mathrm{N}$ - methyl - - aspartate or nitric oxide/superoxide in cortical cell cultures. Proc Acad Sci USA 92, 7162 7166. http://dx.doi.org/10.1073/pnas.92.16.7162.

[4] Carson DA, \& Ribeiro JM (1993). Apoptosis and disease. Lancet 341, 1251 - 1254. http://dx.doi.org/10.1016/0140-6736(93)91154-E.

[5] Chang KL, Liao WT, Yu CL, Cheng CE, Chang LW, \& Yu HS (2003) Effects of $\mathrm{Ga}$ on immune stimulation and apoptosis induction in human peripheral blood mononuclear cells. Toxicol Appl Pharmacol 193, 209 - 217. http://dx.doi.org/10.1016/j.taap.2003.07.004.

[6] Chisolm JJ \& Brown DH (1975). Micro-scale photofluorometric determination of free erythrocyte porphyrin (protoporphyrin IX). Clin Chem 21, $1669-1681$

[7] Chitambar CR (2004). Apoptotic mechanism of gallium nitrate: basic and clinical investigations. Oncology 18 (Suppl 10), $39-44$.

[8] Chimbar CR, Mathacus WG, Antholine WE, Graff K, \& O'Brien WJ (1988). Inhibition of leukemic HL60 cell growth by transferringgallium: effects on ribonucleotide reductase and demonstration of drug synergy with hydroxyurea. Blood 72, 1930 - 1936.

[9] Chitambar CR, Narasimba J, Guy J, Sem DS, \& O'Brein WJ (1991). In hibition of ribonucleotide reductase by $\mathrm{Ga}$ in murine leukemic L1210 cells. Cancer Research 51, 6199 - 6201.

[10]Chitambar CR \& Zorica Z (1987). Inhibition of hemoglobin production by transferring-gallium. Blood $1,144-149$.

[11]Dagg JH, Goldberg A, \& Lochhead (1966). Value of erythrocyte protoporphyrin in the diagnosis of latent iron deficiency (sideropenia). Br J Haematol 12, 326 - 330. http://dx.doi.org/10.1111/j.13652141.1966.tb05638.x.

[12]Distelharst CW (1988). Glucocorticosteroids induce DNA fragmentation in human lymphoid leukemia cell. Blood 72, 1305 - 1309.

[13]Edelman P (1990). Environmental and workplace contamination in the semiconductor industry: implications for future health of the workforce and community. Environ Health Perspect 86, 291 - 295. http://dx.doi.org/10.1289/ehp.9086291. 
[14]Fowler BA, Yamauchi H, Conner EA, \& Akkerman M (1993). Cance risks for humans from exposure to the semiconductor metals. Scand J Work Environ Health 19, 101 - 103.

[15]Granick S, Sassa S, Granick JL, Levere RD, \& Kappas A (1972) Assay for porphyrins, [delta]- aminolevulinic acid dehydratase, and porphyrinogen synthetase in microliter samples of whole blood: applications to metabolic defects involving the heme pathway. Proc Nat $\begin{array}{llllll}\text { Acad } & \text { Sci } & \text { USA } & 69, & 2381 & -\end{array}$ http://dx.doi.org/10.1073/pnas.69.9.2381.

[16] Harris WR \& Pecoraro VL (1983). Thermodynamic binding constants for gallium transferrin. Biochemistry 22, $292 \quad-299$. http://dx.doi.org/10.1021/bi00271a010.

[17]Harthoorn-Lasthuizen EJ, Sant PV, Lindemans J, \& Langenhuijsen M (2000). Serum transferring receptor and erythrocyte zinc protoporphyrin in patients with anemia. Clin Chem 46, $719-722$.

[18]Hastka J, Lasserre JJ, Schwarzbeck A, Strauch M, \& Hehimann R (1993). Zinc protoporphyrin in anemia of chronic disorder. Blood 81 $1200-1204$.

[19]He LF \& Chen JG (2006). DNA damage, apoptosis, and cell cycle changes induced by fluoride in rat oral mucosal cells and hepatocytes World J Gastroenterol 12 (7), 1144 - 1148

[20]Hegde ML, Anitha S, Latha KS, Mustak MS, Stein R, Ravid R, \& Rao KS (2004). First evidence for helical transitions in supercoiled DNA by anyloid beta peptide ( $1-42)$ and $\mathrm{Al}$ : a new insight in understanding Alzheimer's disease. J Mol Neurosci 22, $19 \quad-\quad 31$. http://dx.doi.org/10.1385/JMN:22:1-2:19.

[21] Hingst O \& Blottner S (1995). Quantification of apoptosis (programmed cell death) in mammalian test by DNA-fragmentation ELISA. Theriogenology 44, 313 - 319. http://dx.doi.org/10.1016/0093691X(95)00186-C.

[22] Kasprzak KS (1995). Possible role of oxidative damage in metalinduced carcinogenesis. Cancer Invest 13, $411 \quad-430$ http://dx.doi.org/10.3109/07357909509031921.

[23] Konishi A, Shigeomi S, Hirota J, Takao T, Fan Y, Matsuoka Y, Zhang L, Yoneda Y, Fuji, Skoultchi AI, \& Tsujimoto Y (2003). Involement of histone H1.2 in apoptosis induced by DnA double-strand breaks. Cell 114, 673 - 688. http://dx.doi.org/10.1016/S0092-8674(03)00719 0.

[24]Labbe RF, Rettmer RL, Shah AG, \& Turnlund JR (1987). Zinc protoporphyrin: past, present and future. Ann NY Acad Sci 514, 7 -14 http://dx.doi.org/10.1111/j.1749-6632.1987.tb48755.x.

[25] Larson SM, Rasey JS, Allen DR, Nelson NJ, Grumbaum Z, Harp GD \& Williams DL (1980). Common pathway for tumor cell uptake of gallium-67 and iron-59 via a transferring receptor. J Natl Cancer Inst $64,41-53$.

[26]Liao YH, Hwang LC, Kuo JS, Yiin SJ, Lin SF, Lin CH, \& Aw TC (2006). Lipid peroxidation in workers exposed to $\mathrm{Al}, \mathrm{Ga}, \mathrm{In}, \mathrm{As}$, and $\mathrm{Sb}$ in the optoelectronic industry. J Occup Environ Med 48, 789 - 793. http://dx.doi.org/10.1097/01.jom.0000229782.71756.8e

[27]Liao YH, Yu HS, Ho CK, Wu MT, Yang CY, Chen JR, \& Chang CC (2004). Biological monitoring of exposure to $\mathrm{Al}, \mathrm{Ga}, \mathrm{In}, \mathrm{As}$, and $\mathrm{Sb}$ in optoelectronic industry workers. J Occup Environ Med 46, 931 - 936. http://dx.doi.org/10.1097/01.jom.0000137718.93558.b8

[28] Mischima Y, Terui Y, Mishima Y, Katsuyama M, Mori M, Tomizuka H, Takizaka Y, Miyazato A, Ueda M, Yamada M, Hayasawa H, Mizunuma N, Ishizaka Y, Ikeda K, Kato T, Ozawa K, \& Hatake K (2002). New human myelodysptastic cell line, TER-3: G-CSF specific downregulation of $\mathrm{Ca}+2$ /almodulin-dependent protein kinase IV. J of Cell Pbys 191, 183 - 190

[29]Narasimhan J, Antholine WE, \& Chitambar CR (1992). Effect og gallium on the tyrosul radical of iron-dependent M2 submit of ribonucleotide reductase. Biochem Pharmacol 44, 2403 - 2408. http://dx.doi.org/10.1016/0006-2952(92)90686-D

[30] Ochm A, Behrmann I, Falk W, Pawlita M, Maier G, Klas C, Weber ML, Richards S, Dhein J, Trauth BC, Ponsting H, \& Krammer PK (1992). Purification and molecular cloning the APO-1 cell surface antigen, a member of the tumor necrosis factor/nerve growth factor receptor superfamily. J of Biol Chem 26710709 - 10715.

[31]Pan TC, Horng CJ, Lin SR, Lin TH, \& Huang CW (1993). Stimultaneous determination of $\mathrm{Zn}, \mathrm{Cd}, \mathrm{Pb}$, and $\mathrm{Cu}$ in urine of patient with blackfoot disease using anodic stripping voitammetry. Biol Trace Element Res 38, 233- 250. http://dx.doi.org/10.1007/BF02785308.

[32]Robinson AL (1983). GAAS readied for high-speed microcircuits $\begin{array}{llll}\text { Science } & 219, & 275 & -\end{array}$ http://dx.doi.org/10.1126/science.219.4582.275

[33]Roh YM, Kim K, \& Kim H (2000). Zinc protoporphyrin IX concentrations between normal adults and the $\mathrm{Pb}$-exposed workers measured by HPLC, spetrofluorometer, and hematofluorometer. Indust Health 38 , 372 - 379. http://dx.doi.org/10.2486/indhealth.38.372.
[34]Rosel E, Costin KA, \& Garcia-Webb P (1990). Effect of occupational $\mathrm{Pb}$ exposure on lymphocyte enzymes in heme biosynthesis 36,1980 1983.

[35]Rossi E, Attwood PV, Garcia-Webb P, \& Costin KA (1990). Metal inhibition of ferrochelatase activity in human lymphocytes. Clin Chim Acta 188, 1 - 14. http://dx.doi.org/10.1016/0009-8981(90)90141-E.

[36]Uwai M, Terui Y, Mishima Y, Tomizuka H, Ikeda M, Itoh T, Mori M, Ueda $M$, Inoue R, Yamada M, Hayasawa $H$, Horiuchi $T$, Niho $Y$, Matsumoto M, Ishizaka Y, Ikeda K, Ozawa K, \& Hatake K (2000). A new apoptotic pathway for the complement factor B-derived fragment Bd. J of cell Phys 1985, 280 - 292. http://dx.doi.org/10.1002/10974652(200011)185:2<280::AID-JCP13>3.0.CO;2-L.

[37]Wang AG, Xia T, Chu QL, Zhang M, Liu F, Chen XM, \& Yang KD (2004). Effects of fluoride on lipid peroxidation, DNA damage and apoptosis in human embryo hepatocytes. Biomed Environ Sci 17 (2), $217-222$.

[38]Willianm RD, Riaz UH, Majewski D, \& Lum LG (1996). Modulation of in vitro and in vivo T-cell response by transferring-gallium and gallium nitrate. Blood 8, 3056 - 3064.

[39] Woods JS, Carver GT, \& Fowler BA (1979). Altered regulations of hepatic heme metabolism by indium chloride. Toxicology \& Applied Pharmacology 49, 455 - 461. http://dx.doi.org/10.1016/0041008X(79)90446-0.

[40]Zhou J, Meng R, Sui X, Meng L, Jia J, \& Yang B (2005). Effects of administration styles of arsenic trioxide on intracellular as concentration, cell differentiation and apoptosis. Haematologica 90, 1277 1279 . 